\title{
PHYSICO-CHEMICAL CHARACTERIZATION OF BIOACTIVE MIXED LIGAND COMPLEXES OF ANTIMONY WITH 3,5-DIARYLSUBSTITUTED PYRAZOLINATES AND O,O'-ALKYLENE DITHIOPHOSPHATES
}

\author{
Kanchan Lata Singh ${ }^{1}{ }^{凶}$, Afshan Siddiqui ${ }^{1}$, Kajal Singh $^{1}$, U.N. Tripathi ${ }^{1}$
}

https://doi.org/10.23939/chcht13.04.407

\begin{abstract}
Antimony(III) complexes of 3(2'-hydroxyphenyl)-5-(4'-substituted phenyl) pyrazolinates and O,O'alkylene dithiophosphate of the type $\left[\mathrm{Sb}\left(\mathrm{C}_{15} \mathrm{H}_{12} \mathrm{~N}_{2} \mathrm{OX}\right)\right.$ $\left.\left(\mathrm{GO}_{2} \mathrm{PS}_{2}\right)\right] \mathrm{Cl}$ and $\left[\mathrm{Sb}\left(\mathrm{C}_{15} \mathrm{H}_{12} \mathrm{~N}_{2} \mathrm{OX}\right)_{2}\left(\mathrm{GO}_{2} \mathrm{PS}_{2}\right)\right]$ (where $\mathrm{GO}_{2} \mathrm{PS}_{2}$ - deprotonated $\mathrm{O}, \mathrm{O}$ '-alkylene dithiophosphate; $\mathrm{C}_{15} \mathrm{H}_{12} \mathrm{~N}_{2} \mathrm{OX}$ - deprotonated 3(2'-hydroxyphenyl)-5-(4'subsitutedphenyl) pyrazolinates; $\mathrm{X}=-\mathrm{H},-\mathrm{CH}_{3},-\mathrm{OCH}_{3}$ and $\left.-\mathrm{Cl} ; \mathrm{G}=-\mathrm{C}\left(\mathrm{CH}_{3}\right)_{2} \mathrm{CH}_{2} \mathrm{CH}\left(\mathrm{CH}_{3}\right)-\right)$ have been synthesized and characterized by elemental analysis $(\mathrm{C}, \mathrm{H}, \mathrm{N}, \mathrm{Cl}$ and $\mathrm{Sb}$ ), molecular weight study by FAB mass, electronic spectral studies, far and mid IR, multinuclear NMR $\left({ }^{1} \mathrm{H},{ }^{13} \mathrm{C}\right.$ and $\left.{ }^{31} \mathrm{P}\right)$. On the basis of above spectral studies, coordination of dithiophosphate and pyrazolinates along with the compounds structure have been discussed tentatively. All complexes were tested for in vitro antibacterial and antifungal activity, exhibiting a very good antibacterial and antifungal activity. Few complexes were also tested for their antiviral activity against papya ringspot virus showing a significant antiviral activity with inhibition of approximately $34.30 \%$.
\end{abstract}

Keywords: antibactirial activity, antiviral activity, antimony(III), pyrazolinates, dithiophosphates.

\section{Introduction}

The chemistry of main group metal compounds derived from nitrogen, oxygen and sulphur donor ligands have been an active area of research [1]. There are several reasons for continuing interest in these compounds, such as organoantimony salts are used medically to treat some tropical disease, especially in the treatment of all forms of leishmaniasis [2]. A series of aryl antimony compounds and their in vitro antitumour activities have been reported [3], showing a very high antitumour activity for few of these

\footnotetext{
${ }^{1}$ Department of Chemistry, DDU Gorakhpur University, Gorakhpur 273001, U.P., India

$\triangle$ kanchan100718@gmail.com

(c) Singh K.L., Siddiqui A., Singh K., Tripathi U.N., 2019
}

compounds compared with cisplatin. The synthesis along with spectral studies of dialkyldithiophosphates and dithiophosphinates of arsenic, antimony, bismuth and their organometallic moieties have been reviewed [4]. The interest in the chemistry of main group metals with dithiophosphato ligands arises from their utility as antitumour agents [5].The pyrazolines are an important class of polyazo heterocyclic compounds, showing a wide range of biological activity, such as analgesic [6], antitumor [7], antitussive [8], anti-inflammatory [9], anticonvulsant [10], cardiovascular [11] and antidepressant [12] properties. Pyrazolines are well known for their importance in industries, e.g. as dyes, antioxidants in lubricating oils [13], in agriculture as a catalyst for decarboxylation reactions and as inhibitors for plant growth [14-15]. Complexation behavior of 3(2'-hydroxyphenyl)-5-phenyl) pyrazoline and substituted pyrazolines with arsenic antimony and bismuth have been studied in our laboratories [16-18]. Similar types of ligands were also used for the complexes of tin(IV), organotin(IV) and triorganotin(IV) [19-21]. We have also investigated the complexation behavior of antimony(III) complexes with dithiophosphate ligands [22]. In continuation to our previous work, it was though worthwhile to study the complexation behavior of arsenic(III), antimony(III) and bismuth(III) with 3(2'-hydroxyphenyl)5-(4'-subsitutedphenyl) pyrazolinates and O,O'-alkylene dithiophosphate for comparative bioactivity. In this article, we describe the synthesis, spectral properties and bioactivity of mixed ligand complexes of antimony(III) of 3(2'-hydroxyphenyl)-5-(4'-subsitutedphenyl) pyrazolinates and $\mathrm{O}, \mathrm{O}^{\prime}$-alkylene dithiophosphate.

\section{Experimental}

\subsection{Materials}

Solvents (benzene, isopropanol and ethanol) were rigorously dried and purified by standard methods before use. All chemicals were of analytical grade quality. 
Antimony(III) chloride (E. Merck), sodium metal (SD fine), o-hydroxyacetophenone (CDH), and benzaldehyde (E. Merck) were used without any further purification. Dichloroantimony(III) 3(2'-hydroxyphenyl)-5-(4'-substitutedphenyl) pyrazolines and chloroantimony(III) 3(2'-hydroxyphenyl)-5-(4'-subsitutedphenyl) pyrazolines were prepared by the reported procedure [16]. O,O'-alkylene dithiophosphate was prepared by the reported procedure [23].

\subsection{Synthesis of $\left[\mathrm{Sb}\left(\mathrm{C}_{15} \mathrm{H}_{12} \mathrm{~N}_{2} \mathrm{OX}\right)\left(\mathrm{GO}_{2} \mathrm{PS}_{2}\right)\right] \mathrm{Cl}$}

The new mixed ligand complexes of antimony(III) of the general formula $\left[\mathrm{Sb}\left(\mathrm{C}_{15} \mathrm{H}_{12} \mathrm{~N}_{2} \mathrm{OX}\right)\left(\mathrm{GO}_{2} \mathrm{PS}_{2}\right)\right] \mathrm{Cl}$ were prepared by the reaction of dichloroantimony(III) pyrazolinates and ammonium salt of $\mathrm{O}, \mathrm{O}^{\prime}$-alkylene dithiophosphate in 1:1 molar ratio.

$$
\left[\left(\mathrm{C}_{15} \mathrm{H}_{12} \mathrm{~N}_{2} \mathrm{OX}\right) \mathrm{Sb}\right] \mathrm{Cl}_{2}+\mathrm{NH}_{4} \mathrm{GO}_{2} \mathrm{PS}_{2} \stackrel{\text { Benzene }}{\longrightarrow}\left[\mathrm{Sb}\left(\mathrm{C}_{15} \mathrm{H}_{12} \mathrm{~N}_{2} \mathrm{OX}\right)\left(\mathrm{GO}_{2} \mathrm{PS}_{2}\right)\right] \mathrm{Cl}+\mathrm{NH}_{4} \mathrm{Cl} \downarrow
$$

where $\mathrm{X}=-\mathrm{H},-\mathrm{CH}_{3},-\mathrm{OCH}_{3}$ and $\left.-\mathrm{Cl} ; \mathrm{G}=-\mathrm{C}\left(\mathrm{CH}_{3}\right)_{2} \mathrm{CH}_{2} \mathrm{CH}\left(\mathrm{CH}_{3}\right)-\right] ; \mathrm{GO}_{2} \mathrm{PS}_{2}=$ deprotonated $\mathrm{O}, \mathrm{O}^{\prime}$ alkylene dithiophosphate; $\mathrm{C}_{15} \mathrm{H}_{12} \mathrm{~N}_{2} \mathrm{OX}=$ deprotonated 3(2'-hydroxyphenyl)-5(4'subsitutedphenyl)pyrazolinates.

The benzene suspension of the antimony(III) pyrazolinates ( $1.42 \mathrm{~g}, 3.2 \mathrm{mmol})$ was added dropwise to a slowly stirred benzene suspension of ammonium salt of O,O'-hexylene dithiophosphate $(0.75 \mathrm{~g}, 3.2 \mathrm{mmol})$. The reaction mixture was stirred for $9 \mathrm{~h}$ to ensure the completion of the reaction. The reaction mixture was filtered to remove precipitated $\mathrm{NH}_{4} \mathrm{Cl}(0.16 \mathrm{~g})$ and the filtrate was dried under vacuum. The obtained orange colored solid was recrystallized in acetone at room temperature (purity was further checked by silica gel TLC). $1.78 \mathrm{~g}(89 \%)$ of $\left[\mathrm{Sb}\left(\mathrm{C}_{15} \mathrm{H}_{12} \mathrm{~N}_{2} \mathrm{OX}\right)_{2}\left(\mathrm{GO}_{2} \mathrm{PS}_{2}\right)\right]$ was obtained. Compounds 2-4 were prepared by the same method. The physical and analytical results are presented in Table 1.

Table 1

\section{Synthetic and analytical data for $\left[\mathrm{Sb}\left(\mathrm{C}_{15} \mathrm{H}_{12} \mathrm{~N}_{2} \mathrm{OX}\right)\left(\mathrm{GO}_{2} \mathrm{PS}_{2}\right)\right] \mathrm{Cl}$ and $\left[\mathrm{Sb}\left(\mathrm{C}_{15} \mathrm{H}_{12} \mathrm{~N}_{2} \mathrm{OX}\right)_{2}\left(\mathrm{GO}_{2} \mathrm{PS}_{2}\right)\right]$}

\begin{tabular}{|c|c|c|c|c|c|c|c|c|c|c|}
\hline \multirow[t]{2}{*}{ Comp.no } & \multirow[t]{2}{*}{ Compound } & \multirow[t]{2}{*}{$\begin{array}{c}\text { m.p., } \\
\mathrm{K}\end{array}$} & \multirow[t]{2}{*}{$\begin{array}{c}\text { Yield, } \\
\%\end{array}$} & $\mathrm{C}$ & $\mathrm{H}$ & $\mathrm{N}$ & $\mathrm{S}$ & $\mathrm{Sb}$ & $\mathrm{Cl}$ & $\begin{array}{c}\text { Mol. } \\
\text { weight }\end{array}$ \\
\hline & & & & \multicolumn{7}{|c|}{ (Found/Calcd.) } \\
\hline 1 & {$\left[\mathrm{Sb}\left(\mathrm{C}_{15} \mathrm{H}_{12} \mathrm{~N}_{2} \mathrm{OX}\right)\left(\mathrm{GO}_{2} \mathrm{PS}_{2}\right)\right] \mathrm{Cl}$} & 362 & 87 & $\begin{array}{c}41.52 \\
(41.63)\end{array}$ & $\begin{array}{c}4.10 \\
(4.13)\end{array}$ & $\begin{array}{c}4.58 \\
(4.62)\end{array}$ & $\begin{array}{c}10.46 \\
(10.57)\end{array}$ & $\begin{array}{c}20.02 \\
(20.11)\end{array}$ & $\begin{array}{c}5.80 \\
(5.86)\end{array}$ & $\begin{array}{c}606 \\
(606.25)\end{array}$ \\
\hline 2 & {$\left[\mathrm{Sb}\left(\mathrm{C}_{15} \mathrm{H}_{12} \mathrm{~N}_{2} \mathrm{OX}\right)\left(\mathrm{GO}_{2} \mathrm{PS}_{2}\right)\right] \mathrm{Cl}$} & 355 & 84 & $\begin{array}{c}43.48 \\
(43.63)\end{array}$ & $\begin{array}{c}4.27 \\
(4.36)\end{array}$ & $\begin{array}{c}4.47 \\
(4.52)\end{array}$ & $\begin{array}{c}10.24 \\
(10.33)\end{array}$ & $\begin{array}{c}20.54 \\
(19.66)\end{array}$ & $\begin{array}{c}5.66 \\
(5.73)\end{array}$ & $\begin{array}{c}618 \\
(619.25)\end{array}$ \\
\hline 3 & {$\left[\mathrm{Sb}\left(\mathrm{C}_{15} \mathrm{H}_{12} \mathrm{~N}_{2} \mathrm{OX}\right)\left(\mathrm{GO}_{2} \mathrm{PS}_{2}\right)\right] \mathrm{Cl}$} & 359 & 90 & $\begin{array}{c}41.40 \\
(41.55)\end{array}$ & $\begin{array}{c}4.20 \\
(4.25)\end{array}$ & $\begin{array}{c}4.34 \\
(4.40)\end{array}$ & $\begin{array}{c}9.97 \\
(10.07)\end{array}$ & $\begin{array}{c}19.06 \\
(19.16)\end{array}$ & $\begin{array}{c}5.49 \\
(5.58)\end{array}$ & $\begin{array}{c}635 \\
(635.25)\end{array}$ \\
\hline 4 & {$\left[\mathrm{Sb}\left(\mathrm{C}_{15} \mathrm{H}_{12} \mathrm{~N}_{2} \mathrm{OX}\right)\left(\mathrm{GO}_{2} \mathrm{PS}_{2}\right)\right] \mathrm{Cl}$} & 363 & 86 & $\begin{array}{c}39.48 \\
(39.39)\end{array}$ & $\begin{array}{c}3.68 \\
(4.75)\end{array}$ & $\begin{array}{c}4.32 \\
(4.37)\end{array}$ & $\begin{array}{c}9.93 \\
(10.00)\end{array}$ & $\begin{array}{c}18.97 \\
(19.03)\end{array}$ & $\begin{array}{c}11.00 \\
(11.09)\end{array}$ & $\begin{array}{c}639 \\
(639.75)\end{array}$ \\
\hline 5 & {$\left[\mathrm{Sb}\left(\mathrm{C}_{15} \mathrm{H}_{12} \mathrm{~N}_{2} \mathrm{OX}\right)_{2}\left(\mathrm{GO}_{2} \mathrm{PS}_{2}\right)\right]$} & 348 & 85 & $\begin{array}{c}53.40 \\
(53.54)\end{array}$ & $\begin{array}{c}4.64 \\
(4.71)\end{array}$ & $\begin{array}{c}6.90 \\
(6.94)\end{array}$ & $\begin{array}{c}7.85 \\
(7.93)\end{array}$ & $\begin{array}{c}15.01 \\
(15.09)\end{array}$ & - & $\begin{array}{c}804 \\
(806.75)\end{array}$ \\
\hline 6 & {$\left[\mathrm{Sb}\left(\mathrm{C}_{15} \mathrm{H}_{12} \mathrm{~N}_{2} \mathrm{OX}\right)_{2}\left(\mathrm{GO}_{2} \mathrm{PS}_{2}\right)\right]$} & 353 & 82 & $\begin{array}{c}54.48 \\
(54.62)\end{array}$ & $\begin{array}{c}4.98 \\
(5.03)\end{array}$ & $\begin{array}{c}6.62 \\
(6.70)\end{array}$ & $\begin{array}{c}7.56 \\
(7.66)\end{array}$ & $\begin{array}{c}14.43 \\
(14.58)\end{array}$ & - & $\begin{array}{c}832 \\
(834.75)\end{array}$ \\
\hline 7 & {$\left[\mathrm{Sb}\left(\mathrm{C}_{15} \mathrm{H}_{12} \mathrm{~N}_{2} \mathrm{OX}\right)_{2}\left(\mathrm{GO}_{2} \mathrm{PS}_{2}\right)\right]$} & 348 & 83 & $\begin{array}{c}51.47 \\
(52.61)\end{array}$ & $\begin{array}{c}4.75 \\
(4.84)\end{array}$ & $\begin{array}{c}6.39 \\
(6.46)\end{array}$ & $\begin{array}{c}7.31 \\
(7.38)\end{array}$ & $\begin{array}{c}13.96 \\
(14.04)\end{array}$ & - & $\begin{array}{c}865 \\
(866.75)\end{array}$ \\
\hline 8 & {$\left[\mathrm{Sb}\left(\mathrm{C}_{15} \mathrm{H}_{12} \mathrm{~N}_{2} \mathrm{OX}\right)_{2}\left(\mathrm{GO}_{2} \mathrm{PS}_{2}\right)\right]$} & 352 & 81 & $\begin{array}{c}48.27 \\
(49.32)\end{array}$ & $\begin{array}{c}4.07 \\
(4.11)\end{array}$ & $\begin{array}{c}6.32 \\
(6.39)\end{array}$ & $\begin{array}{c}7.25 \\
(7.30)\end{array}$ & $\begin{array}{c}13.84 \\
(13.90)\end{array}$ & $\begin{array}{c}7.95 \\
(8.10)\end{array}$ & $\begin{array}{c}874 \\
(875.75)\end{array}$ \\
\hline
\end{tabular}

Notes: $\mathrm{X}=\mathrm{H}$ for $\mathbf{1}$ and $\mathbf{5} ; \mathrm{CH}_{3}$ for $\mathbf{2}$ and $\mathbf{6} ; \mathrm{OCH}_{3}$ for $\mathbf{3}$ and $\mathbf{7} ; \mathrm{Cl}$ for $\mathbf{4}$ and $\mathbf{8} ; \mathrm{G}=-\mathrm{C}\left(\mathrm{CH}_{3}\right)_{2} \mathrm{CH}_{2} \mathrm{CH}\left(\mathrm{CH}_{3}\right)^{-}$ 


\subsection{Synthesis of $\left[\mathrm{Sb}\left(\mathrm{C}_{15} \mathrm{H}_{12} \mathrm{~N}_{2} \mathrm{OX}\right)_{2}\left(\mathrm{GO}_{2} \mathrm{PS}_{2}\right)\right]$}

The new mixed ligand complexes of antimony(III) of the general formula $\left[\mathrm{Sb}\left(\mathrm{C}_{15} \mathrm{H}_{12} \mathrm{~N}_{2} \mathrm{OX}\right)_{2}\left(\mathrm{GO}_{2} \mathrm{PS}_{2}\right)\right]$ were prepared by the reaction of chloroantimony(III) dipyrazolinates and ammonium salt of $\mathrm{O}, \mathrm{O}$ '-alkylene dithiophosphate in 1:1 molar ratio.

$$
\left[\left(\mathrm{C}_{15} \mathrm{H}_{12} \mathrm{~N}_{2} \mathrm{O} . \mathrm{X}\right)_{2} \mathrm{Sb}\right] \mathrm{Cl}+\mathrm{NH}_{4} \mathrm{GO}_{2} \mathrm{PS}_{2} \stackrel{\text { Benzene }}{\longrightarrow}\left[\mathrm{Sb}\left(\mathrm{C}_{15} \mathrm{H}_{12} \mathrm{~N}_{2} \mathrm{O} . \mathrm{X}\right)_{2}\left(\mathrm{GO}_{2} \mathrm{PS}_{2}\right)\right]+\mathrm{NH}_{4} \mathrm{Cl} \downarrow
$$

where $\mathrm{X}=-\mathrm{H},-\mathrm{CH}_{3},-\mathrm{OCH}_{3},-\mathrm{Cl} ; \mathrm{G}=-\mathrm{C}\left(\mathrm{CH}_{3}\right)_{2} \mathrm{CH}_{2} \mathrm{CH}\left(\mathrm{CH}_{3}\right)-; \mathrm{GO}_{2} \mathrm{PS}_{2}=$ deprotonated O,O'-alkylene dithiophosphate; $\mathrm{C}_{15} \mathrm{H}_{12} \mathrm{~N}_{2} \mathrm{OX}$ = deprotonated 3(2'-hydroxyphenyl)-5-(4'-subsitutedphenyl) pyrazolinates

A benzene solution of antimony(III) dipyrazolinates $(1.56 \mathrm{~g}, 2.4 \mathrm{mmol})$ was added dropwise to the benzene suspension of ammonium salt of $\mathrm{O}, \mathrm{O}$ '-hexylene dithiophosphate $(0.56 \mathrm{~g}, 2.4 \mathrm{mmol})$ under constant stirring. The reaction mixture was stirred for $9 \mathrm{~h}$ to ensure the completion of the reaction. The reaction mixture was filtered to remove precipitated $\mathrm{NH}_{4} \mathrm{Cl}(0.13 \mathrm{~g})$ and the filtrate was dried under vaccum. The dark orange colored solid was recystallized in acetone at room temperature (purity was further checked by TLC). $1.50 \mathrm{~g} \mathrm{(75 \% )} \mathrm{of}$ $\left[\mathrm{Sb}\left(\mathrm{C}_{15} \mathrm{H}_{12} \mathrm{~N}_{2} \mathrm{OX}\right)_{2}\left(\mathrm{GO}_{2} \mathrm{PS}_{2}\right)\right]$ was obtained. Compounds 6-8 were prepared by the same method. The physical and analytical results are presented in Table 1.

\subsection{Physical Measurements}

Chlorine was estimated by Volhard's method [24] and antimony was estimated iodometrically [24]. Infrared spectra were recorded on Varian 3100 FT-IR spectrophotometer in the range of $4000-50 \mathrm{~cm}^{-1}$. The ${ }^{1} \mathrm{H}$ NMR spectra and proton decoupled ${ }^{13} \mathrm{C}$ NMR spectra were recorded at room temperature in $\mathrm{CDCl}_{3}$ on a JEOL AL 300 spectrometer, operated at 300.1 and $74.45 \mathrm{MHz}$ for ${ }^{1} \mathrm{H}$ and ${ }^{3} \mathrm{C}$, using TMS (tetramethylsilane) as internal standard. ${ }^{31} \mathrm{P}$ NMR spectra were recorded in $\mathrm{C}_{6} \mathrm{H}_{6}$ solution on a Bruker Avance $400 \mathrm{NMR}$ at $161.9 \mathrm{MHz}$ using $\mathrm{H}_{3} \mathrm{PO}_{3}$ as an internal standard. The elemental analysis $(\mathrm{C}, \mathrm{H}$ and $\mathrm{N}$ ) was obtained by using a Coleman $\mathrm{CHN}$ analyzer. The specific optical rotations were recorded at $298 \mathrm{~K}$ in benzene on Perkin-Elmer polarimeter (model 341) using the sodium D line $(\lambda=589 \mathrm{~nm})$. Electronic spectra were recorded in benzene solution on Hitachi UV-2000 UV-visible spectrophotometer within the range of 400-200 nm.

\subsection{Antimicrobial Studies}

Agar disc diffusion technique was used for screening in vitro antimicrobial activity [25]. Inoculums of bacteria were prepared in a nutrient broth and fungi in a potato dextrose agar slant. The cultures were inoculated and incubated for $48 \mathrm{~h}$ in case of bacteria and 5 days for fungi. Molten Muller Hinton medium was poured in a sterile Petri dish $(9 \mathrm{~cm}$ in diameter) to get a depth of $5 \mathrm{~mm}$. The medium was left to solidify and then seeded with respective test organisms. For the purpose of seeding, $5 \mathrm{ml}$ of sterile water was added to the agar slant culture of fungi. The culture was scraped to get suspension of fungi spore. A sterile cotton swab was dipped in the culture/suspension and lightly rubbed over the solidified medium. The plate was left for a few minutes and then used for the test. $30 \mu \mathrm{m}$ of each sample to be tested was dissolved in $1 \mathrm{ml}$ of acetone. $5 \mathrm{~mm}$ discs of Whatman filter paper no.40 were cut and sterilized. The filter paper discs were immersed in the solution of a sample, after soaking; the disc was removed and left in a sterile Petri dish to permit the solvent to evaporate. After about $10 \mathrm{~min}$ the paper discs were transferred to seeded agar plate. Discs were kept on the seeded agar plates. Finally the dishes were incubated at $310 \mathrm{~K}$ for $24 \mathrm{~h}$ (for bacteria) and at 303 for $72 \mathrm{~h}$ (for fungi), where clear or inhibition zones were detected around each disc. A disc soaked in DMSO alone was used as a control under the same conditions and there was no inhibition zone. Each distinct inhibition zone was measured as a diameter in $\mathrm{mm}$, both antibacterial and antifungal activity was calculated as a mean of three replicates.

\subsection{Antiviral Testing}

Pure cultures of Papaya ring spot virus (PRSV) were maintained on Carica papaya plants in a glass house. Local lesion bioassay method [26] was performed to study the antiviral properties of the various compounds against the test virus.

Powder samples of compounds were prepared in various dilutions from 1:10 and 1:20 with inoculation buffer. $1 \mathrm{ml}$ was mixed with $1 \mathrm{ml}$ of freshly prepared viral inoculums and incubated for $30 \mathrm{~min}$ in cold conditions; later the inoculum was inoculated to local lesion assay seeding by using the small piece of muslin cloth. For control, some of the seedlings were being maintained in insect mesh house for observation. Three independent replications were performed; in each experiment 10 seedlings were used for each dilution for testing of antiviral property.

Local lesions which appeared on tested and control chenopodium plants were counted and per cent antiviral activity was calculated by the formula (1).

$$
\text { Percent antiviral activity }=(C-T) / T \cdot 100
$$

where $C$ is a number of local lesions on control leaves; $T$ is a number of local lesions on tested leaves. 


\section{Results and Discussion}

All the compounds are orange colored solids, stable at room temperature, soluble in common organic (chloroform, acetone, alcohol) and coordinating solvent (tetrahydrofuran, dimethylformamide and dimethylsulphoxide). The FAB mass spectra show the monomeric nature of these compounds. The elemental analysis $(\mathrm{C}, \mathrm{H}$, $\mathrm{N}, \mathrm{P}, \mathrm{S}, \mathrm{Cl}$ and $\mathrm{Sb}$ ) data is in accordance with a stoichiometry proposed for respective compounds (Table 1).

\subsection{Specific Optical Rotation Data}

The specific optical rotation values of benzene solution of free pyrazolines and mixed ligand complexes of antimony(III) are not measurable at the concentration of $1.00,0.50,0.10$ and $0.05 \%$. All the four free pyrazoline ligands show zero specific optical rotation at $0.02 \%$ concentration. Thus free pyrazolines are racemic mixture. The specific optical rotation values for mixed ligand complexes of antimony(III) in the benzene solution at $0.02 \%$ concentration are also zero indicating the presence of racemic mixture.

\subsection{Infrared Spectral Studies}

The infrared spectra of the complexes recorded in the range of $4000-50 \mathrm{~cm}^{-1}$ and assignments made on the basis of previous reports are summarized in Table 2. All compounds exhibit the band of medium intensity in the region of $3435-3412 \mathrm{~cm}^{-1}$ due to $v(\mathrm{~N}-\mathrm{H})$ stretching vibrations and band in the region of $1634-1620 \mathrm{~cm}^{-1}$ due to $v(\mathrm{C}=\mathrm{N})$ stretching vibrations [16-21, 27-28]. The signal due to $v(\mathrm{O}-\mathrm{H})$ (originally present at $\sim 3085 \mathrm{~cm}^{-1}$ in the free pyrazolines) is completely disappeared from the spectra of the complexes. The appearance of two new bands (in comparison to free pyrazolines ) in the region of 478-458 and $447-429 \mathrm{~cm}^{-1}$ are assigned to $\mathrm{v}(\mathrm{Sb}-\mathrm{O})$ and $\mathrm{v}(\mathrm{Sb}-\mathrm{N})$ stretching vibrations, respectively [16]. The appearance of two new bands due to $\mathrm{Sb}-\mathrm{O}$ and $\mathrm{Sb}-\mathrm{N}$, as well as the absence of hydroxyl band suggest that pyrazoline behaves as a monobasic bidentate ligand in these compounds.

The infrared spectra of these newly synthesized complexes also show medium to strong intensity bands in the region of $1132-1110$ and $898-879 \mathrm{~cm}^{-1}$ have been assigned to $[(\mathrm{P})-\mathrm{OC}]$ and $[\mathrm{P}-\mathrm{O}(\mathrm{C})]$ stretching vibrations, respectively [29-30]. A sharp band in the region of 922$910 \mathrm{~cm}^{-1}$ was assigned to ring vibrations of dioxaphosphorinane ring [29-30]. The band for $[\mathrm{P}=\mathrm{S}$ ] was found in $687-670 \mathrm{~cm}^{-1}$ region and it was observed that, in comparison with the spectra of the parent alkylenedithiophosphoric acids, there is a shifting towards lower frequency [29-30]. This shifting indicates a bidentate chelation of thiophosphoryl sulphurs to antimony. The bands of weak to medium intensities in the region of $598-585 \mathrm{~cm}^{-1}$ were due to $\mathrm{P}-\mathrm{S}$ stretching vibration [29-30]. The O,O'-alkylene dithiophosphate ligands are isodentate in nature but upon coordination with the antimony these ligands shows anisodentate behavior. Distortion in the coordination polyhedra may occur due to the steriochemically active lone pair of electrons and small ligand bite. The band of weak intensity at $387-364 \mathrm{~cm}^{-1}$ occurs due to $\mathrm{Sb}-\mathrm{S}$ stretching vibration $[22,31]$. Thus the presence of one new band due to $\mathrm{Sb}-\mathrm{S}$ and shifting of $[\mathrm{P}=\mathrm{S}]$ band indicating the bidentate nature of $\mathrm{O}, \mathrm{O}^{\prime}$-alkylene dithiophosphate (Table 2).

Table 2

\section{IR spectral data $\left(\mathrm{cm}^{-1}\right)$ for $\left[\mathrm{Sb}\left(\mathrm{C}_{15} \mathrm{H}_{12} \mathrm{~N}_{2} \mathrm{OX}\right)\left(\mathrm{GO}_{2} \mathrm{PS}_{2}\right)\right] \mathrm{Cl}$ and $\left[\mathrm{Sb}\left(\mathrm{C}_{15} \mathrm{H}_{12} \mathrm{~N}_{2} \mathrm{OX}\right)_{2}\left(\mathbf{G O}_{2} \mathrm{PS}_{2}\right)\right]$}

\begin{tabular}{|c|c|c|c|c|c|c|c|c|c|c|c|c|}
\hline 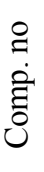 & 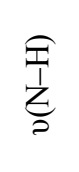 & 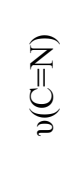 & 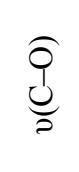 & 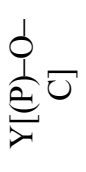 & 品. & $\begin{array}{l}\widetilde{\tilde{\theta}} \\
0 \\
0 \\
\frac{\partial}{2}\end{array}$ & $\begin{array}{l}0 \\
e_{0}\end{array}$ & $\begin{array}{l}\widehat{a} \\
\hat{1} \\
\qquad \underbrace{}_{0}\end{array}$ & $\begin{array}{l}\hat{0} \\
0 \\
\text { क्टे }\end{array}$ & $\begin{array}{l}\widehat{Z} \\
\text { है } \\
\text { है }\end{array}$ & $\begin{array}{l}\widehat{D} \\
\frac{1}{\hat{n}} \\
\text { D. }\end{array}$ & 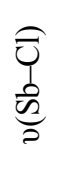 \\
\hline 1 & 3412 & 1624 & - & 1125 & 912 & 890 & 680 & 595 & 478 & 447 & 387 & 336 \\
\hline 2 & 3435 & 1632 & - & 1114 & 915 & 889 & 682 & 597 & 467 & 429 & 376 & 338 \\
\hline 3 & 3426 & 1620 & 1017 & 1113 & 914 & 898 & 670 & 585 & 465 & 443 & 368 & 321 \\
\hline 4 & 3427 & 1623 & - & 1110 & 920 & 879 & 687 & 598 & 471 & 434 & 364 & 328 \\
\hline 5 & 3434 & 1626 & - & 1120 & 922 & 891 & 683 & 598 & 468 & 443 & 386 & - \\
\hline 6 & 3427 & 1628 & - & 1132 & 913 & 886 & 672 & 592 & 476 & 431 & 379 & - \\
\hline 7 & 3413 & 1634 & 1014 & 1123 & 920 & 890 & 674 & 590 & 472 & 440 & 373 & - \\
\hline 8 & 3412 & 1626 & - & 1125 & 910 & 883 & 679 & 592 & 477 & 441 & 381 & - \\
\hline
\end{tabular}

Notes: $\mathrm{X}=\mathrm{H}$ for $\mathbf{1}$ and $\mathbf{5} ; \mathrm{CH}_{3}$ for $\mathbf{2}$ and $\mathbf{6} ; \mathrm{OCH}_{3}$ for $\mathbf{3}$ and $\mathbf{7} ; \mathrm{Cl}$ for $\mathbf{4}$ and $\mathbf{8} ; \mathrm{G}=-\mathrm{C}\left(\mathrm{CH}_{3}\right)_{2} \mathrm{CH}_{2} \mathrm{CH}_{(}\left(\mathrm{CH}_{3}\right)-$ 


\section{3. ${ }^{1} \mathrm{H}$ NMR Spectral Studies}

The ${ }^{1} \mathrm{H}$ chemical shifts of all compounds are listed in Table 3. In ${ }^{1} \mathrm{H}$ NMR spectra of $\left[\mathrm{Sb}\left(\mathrm{C}_{15} \mathrm{H}_{12} \mathrm{~N}_{2} \mathrm{OX}\right)\right.$ $\left.\left(\mathrm{GO}_{2} \mathrm{PS}_{2}\right)\right] \mathrm{Cl}$ and $\left[\mathrm{Sb}\left(\mathrm{C}_{15} \mathrm{H}_{12} \mathrm{~N}_{2} \mathrm{OX}\right)_{2}\left(\mathrm{GO}_{2} \mathrm{PS}_{2}\right)\right]$, the benzene ring protons were observed as multiplet in the region of 7.9-6.4 ppm [16-21, 27-28]. The peak due to hydroxyl proton (originally present at $\delta \sim 11.00 \mathrm{ppm}$ in free pyrazolines) is absent from the spectra of the complexes suggesting the bonding through hydroxyl oxygen atom [16-21, 27-28]. The appearance of a peak at $\delta=5.5-5.1 \mathrm{ppm}$ as a broad signal could be assigned to $\mathrm{N}-\mathrm{H}$ group (originally present at $\delta=5.5-5.3 \mathrm{ppm}$ in free pyrazolines) suggesting the non-involvement of $\mathrm{N}-\mathrm{H}$ group in bond formation [16-21, 27-28]. The skeletal protons of five membered ring are observed at $\delta=3.4-3.0 \mathrm{ppm}$ as a triplet and at $\delta=2.5-2.0 \mathrm{ppm}$ as a doublet. They could be assigned to $\mathrm{CH}$ and $\mathrm{CH}_{2}$ group, respectively [16-21, 27-28]. The $-\mathrm{CH}_{3}$ and $-\mathrm{CH}_{2}$ protons of alkylene dithiophosphate show multiplet in the region of 1.6-1.1 ppm [29-30] and the -OCH protons coupled with ${ }^{31} \mathrm{P}$ nuclei to get multiplet in the region of 5.0-4.2 ppm [29-30]. The observed integration ratio was found well with the presence of one dithiophosphate and two pyrazoline ligands in the complexes.

Table 3

${ }^{1} \mathrm{H}$ NMR spectral data for $\left[\mathrm{Sb}\left(\mathrm{C}_{15} \mathrm{H}_{12} \mathrm{~N}_{2} \mathrm{OX}\right)\left(\mathrm{GO}_{2} \mathrm{PS}_{2}\right)\right] \mathrm{Cl}$ and $\left[\mathrm{Sb}\left(\mathrm{C}_{15} \mathrm{H}_{12} \mathrm{~N}_{2} \mathrm{OX}\right)_{2}\left(\mathrm{GO}_{2} \mathrm{PS}_{2}\right)\right]$

\begin{tabular}{|c|c|c|c|}
\hline \multirow{2}{*}{ Comp.no } & \multirow{2}{*}{ Compounds } & \multicolumn{2}{|c|}{ Chemical shift $\delta, \mathrm{ppm}$} \\
\hline & & Pyrazoline & Dtp \\
\hline 1 & {$\left[\mathrm{Sb}\left(\mathrm{C}_{15} \mathrm{H}_{12} \mathrm{~N}_{2} \mathrm{OX}\right)\left(\mathrm{GO}_{2} \mathrm{PS}_{2}\right)\right] \mathrm{Cl}$} & $\begin{array}{c}7.6-6.8(13 \mathrm{H}, \mathrm{m}, \mathrm{Ar}-\mathrm{H}) \\
5.3(2 \mathrm{H}, \mathrm{s}, \mathrm{NH}) \\
3.3(1 \mathrm{H}, \mathrm{t}, \mathrm{CH}) \\
2.5\left(2 \mathrm{H}, \mathrm{d}, \mathrm{CH}_{2}\right)\end{array}$ & $\begin{array}{c}1.1\left(\mathrm{~m}, 9 \mathrm{H}-\mathrm{CH}_{3}\right) \\
4.8(\mathrm{~m}, 1 \mathrm{H}, \mathrm{OCH}-)\end{array}$ \\
\hline 2 & {$\left[\mathrm{Sb}\left(\mathrm{C}_{15} \mathrm{H}_{12} \mathrm{~N}_{2} \mathrm{OX}\right)\left(\mathrm{GO}_{2} \mathrm{PS}_{2}\right)\right] \mathrm{Cl}$} & $\begin{array}{c}7.9-6.4(13 \mathrm{H}, \mathrm{m}, \mathrm{Ar}-\mathrm{H}) \\
5.5(2 \mathrm{H}, \mathrm{s}, \mathrm{NH}) \\
3.0(1 \mathrm{H}, \mathrm{t}, \mathrm{CH}) \\
2.3\left(2 \mathrm{H}, \mathrm{d}, \mathrm{CH}_{2}\right) \\
0.9\left(3 \mathrm{H}, \mathrm{s}, \mathrm{CH}_{3}\right)\end{array}$ & $\begin{array}{c}1.4\left(\mathrm{~s}, 9 \mathrm{H}-\mathrm{CH}_{3}\right) \\
4.9-4.3(\mathrm{~m}, 2 \mathrm{H}, \mathrm{OCH}-)\end{array}$ \\
\hline 3 & {$\left[\mathrm{Sb}\left(\mathrm{C}_{15} \mathrm{H}_{12} \mathrm{~N}_{2} \mathrm{OX}\right)\left(\mathrm{GO}_{2} \mathrm{PS}_{2}\right)\right] \mathrm{Cl}$} & $\begin{array}{c}7.8-6.7(13 \mathrm{H}, \mathrm{m}, \mathrm{Ar}-\mathrm{H}) \\
5.4(2 \mathrm{H}, \mathrm{s}, \mathrm{NH}) \\
3.1(1 \mathrm{H}, \mathrm{t}, \mathrm{CH}) \\
2.0\left(2 \mathrm{H}, \mathrm{d}, \mathrm{CH}_{2}\right) \\
3.6\left(3 \mathrm{H}, \mathrm{s}, \mathrm{OCH}_{3}\right)\end{array}$ & $\begin{array}{c}1.5\left(\mathrm{~s}, 9 \mathrm{H}-\mathrm{CH}_{3}\right) \\
4.9-4.2(\mathrm{~m}, 2 \mathrm{H}, \mathrm{OCH}-)\end{array}$ \\
\hline 4 & {$\left[\mathrm{Sb}\left(\mathrm{C}_{15} \mathrm{H}_{12} \mathrm{~N}_{2} \mathrm{OX}\right)\left(\mathrm{GO}_{2} \mathrm{PS}_{2}\right)\right] \mathrm{Cl}$} & $\begin{array}{c}7.6-6.5(13 \mathrm{H}, \mathrm{m}, \mathrm{Ar}-\mathrm{H}) \\
5.5(2 \mathrm{H}, \mathrm{s}, \mathrm{NH}) \\
3.3(1 \mathrm{H}, \mathrm{t}, \mathrm{CH}) \\
2.1\left(2 \mathrm{H}, \mathrm{d}, \mathrm{CH}_{2}\right) \\
\end{array}$ & $\begin{array}{c}1.6\left(\mathrm{~s}, 9 \mathrm{H}-\mathrm{CH}_{3}\right) \\
5.0-4.4(\mathrm{~m}, 2 \mathrm{H}, \mathrm{OCH}-)\end{array}$ \\
\hline 5 & {$\left[\mathrm{Sb}\left(\mathrm{C}_{15} \mathrm{H}_{12} \mathrm{~N}_{2} \mathrm{OX}\right)_{2}\left(\mathrm{GO}_{2} \mathrm{PS}_{2}\right)\right]$} & $\begin{array}{c}7.7-6.8(13 \mathrm{H}, \mathrm{m}, \mathrm{Ar}-\mathrm{H}) \\
5.1(2 \mathrm{H}, \mathrm{s}, \mathrm{NH}) \\
3.3(1 \mathrm{H}, \mathrm{t}, \mathrm{CH}) \\
2.3\left(2 \mathrm{H}, \mathrm{d}, \mathrm{CH}_{2}\right)\end{array}$ & $\begin{array}{c}1.3\left(\mathrm{~s}, 9 \mathrm{H}-\mathrm{CH}_{3}\right) \\
4.8-4.4(\mathrm{~m}, 2 \mathrm{H}, \mathrm{OCH}-)\end{array}$ \\
\hline 6 & {$\left[\mathrm{Sb}\left(\mathrm{C}_{15} \mathrm{H}_{12} \mathrm{~N}_{2} \mathrm{OX}\right)_{2}\left(\mathrm{GO}_{2} \mathrm{PS}_{2}\right)\right]$} & $\begin{array}{c}7.6-6.5(13 \mathrm{H}, \mathrm{m}, \mathrm{Ar}-\mathrm{H}) \\
5.2(2 \mathrm{H}, \mathrm{s}, \mathrm{NH}) \\
3.4(1 \mathrm{H}, \mathrm{t}, \mathrm{CH}) \\
2.4\left(2 \mathrm{H}, \mathrm{d}, \mathrm{CH}_{2}\right) \\
0.9\left(3 \mathrm{H}, \mathrm{s}, \mathrm{CH}_{3}\right) \\
\end{array}$ & $\begin{array}{c}1.6\left(\mathrm{~s}, 9 \mathrm{H}-\mathrm{CH}_{3}\right) \\
4.9-4.6(\mathrm{~m}, 2 \mathrm{H}, \mathrm{OCH}-)\end{array}$ \\
\hline 7 & {$\left[\mathrm{Sb}\left(\mathrm{C}_{15} \mathrm{H}_{12} \mathrm{~N}_{2} \mathrm{OX}\right)_{2}\left(\mathrm{GO}_{2} \mathrm{PS}_{2}\right)\right]$} & $\begin{array}{c}\text { 7.6-6.7 (13H, m, Ar-H) } \\
5.2(2 \mathrm{H}, \mathrm{s}, \mathrm{NH}) \\
3.3(1 \mathrm{H}, \mathrm{t}, \mathrm{CH}) \\
2.5\left(2 \mathrm{H}, \mathrm{d}, \mathrm{CH}_{2}\right) \\
3.9\left(3 \mathrm{H}, \mathrm{s}, \mathrm{OCH}_{3}\right)\end{array}$ & $\begin{array}{c}1.5\left(\mathrm{~s}, 9 \mathrm{H}-\mathrm{CH}_{3}\right) \\
5.0-4.5(\mathrm{~m}, 2 \mathrm{H}, \mathrm{OCH}-)\end{array}$ \\
\hline 8 & {$\left[\mathrm{Sb}\left(\mathrm{C}_{15} \mathrm{H}_{12} \mathrm{~N}_{2} \mathrm{OX}\right)_{2}\left(\mathrm{GO}_{2} \mathrm{PS}_{2}\right)\right]$} & $\begin{array}{c}7.8-6.6(13 \mathrm{H}, \mathrm{m}, \mathrm{Ar}-\mathrm{H}) \\
5.4(2 \mathrm{H}, \mathrm{s}, \mathrm{NH}) \\
3.0(1 \mathrm{H}, \mathrm{t}, \mathrm{CH}) \\
2.3\left(2 \mathrm{H}, \mathrm{d}, \mathrm{CH}_{2}\right) \\
\end{array}$ & $\begin{array}{c}1.4\left(\mathrm{~s}, 9 \mathrm{H}-\mathrm{CH}_{3}\right) \\
4.8-4.3(\mathrm{~m}, 2 \mathrm{H}, \mathrm{OCH}-)\end{array}$ \\
\hline
\end{tabular}

Notes: $\mathrm{X}=\mathrm{H}$ for $\mathbf{1}$ and $\mathbf{5} ; \mathrm{CH}_{3}$ for $\mathbf{2}$ and $\mathbf{6} ; \mathrm{OCH}_{3}$ for $\mathbf{3}$ and $\mathbf{7} ; \mathrm{Cl}$ for $\mathbf{4}$ and $\mathbf{8} ; \mathrm{G}=-\mathrm{C}\left(\mathrm{CH}_{3}\right)_{2} \mathrm{CH}_{2} \mathrm{CH}\left(\mathrm{CH}_{3}\right)-$; Dtp $=\mathrm{O}, \mathrm{O}$ alkylene dithiophosphate 
${ }^{31} \mathrm{C}$ NMR spectral data for $\left[\mathrm{Sb}\left(\mathrm{C}_{15} \mathrm{H}_{12} \mathrm{~N}_{2} \mathrm{OX}\right)\left(\mathrm{GO}_{2} \mathrm{PS}_{2}\right)\right] \mathrm{Cl}$ and $\left[\mathrm{Sb}\left(\mathrm{C}_{15} \mathrm{H}_{12} \mathrm{~N}_{2} \mathrm{OX}\right)_{2}\left(\mathrm{GO}_{2} \mathrm{PS}_{2}\right)\right]$

\begin{tabular}{|c|c|c|c|c|}
\hline \multirow{3}{*}{ Comp.no } & \multirow{3}{*}{ Compounds } & \multicolumn{3}{|c|}{ Chemical shift $\delta, \mathrm{ppm}$} \\
\hline & & \multicolumn{2}{|c|}{${ }^{13} \mathrm{C}$ NMR } & \multirow{2}{*}{${ }^{31} \mathrm{P}$ NMR } \\
\hline & & Pyrazoline & Dtp & \\
\hline 1 & {$\left[\mathrm{Sb}\left(\mathrm{C}_{15} \mathrm{H}_{12} \mathrm{~N}_{2} \mathrm{OX}\right)\left(\mathrm{GO}_{2} \mathrm{PS}_{2}\right)\right] \mathrm{Cl}$} & $\begin{array}{c}144.1-124.0(\mathrm{Ar}-\mathrm{C}) \\
159.0(\mathrm{C}=\mathrm{N}) \\
46.3(\mathrm{CH}) \\
27.8\left(\mathrm{CH}_{2}\right)\end{array}$ & $\begin{array}{c}\text { 83.1(OC) } \\
77.4(\mathrm{OCH}) \\
22.0\left(\mathrm{CH}_{2}\right) \\
14.3\left(\mathrm{CH}_{3}\right)\end{array}$ & 98.2 \\
\hline 2 & {$\left[\mathrm{Sb}\left(\mathrm{C}_{15} \mathrm{H}_{12} \mathrm{~N}_{2} \mathrm{OX}\right)\left(\mathrm{GO}_{2} \mathrm{PS}_{2}\right)\right] \mathrm{Cl}$} & $\begin{array}{c}144.6-124.5(\mathrm{Ar}-\mathrm{C}) \\
159.1(\mathrm{C}=\mathrm{N}) \\
47.5(\mathrm{CH}) \\
28.4\left(\mathrm{CH}_{2}\right) \\
51.5\left(\mathrm{CH}_{3}\right)\end{array}$ & $\begin{array}{c}84.5(\mathrm{OC}) \\
78.1(\mathrm{OCH}) \\
22.9\left(\mathrm{CH}_{2}\right) \\
13.8\left(\mathrm{CH}_{3}\right)\end{array}$ & 99.1 \\
\hline 3 & {$\left[\mathrm{Sb}\left(\mathrm{C}_{15} \mathrm{H}_{12} \mathrm{~N}_{2} \mathrm{OX}\right)\left(\mathrm{GO}_{2} \mathrm{PS}_{2}\right)\right] \mathrm{Cl}$} & $\begin{array}{c}143.8-123.9(\mathrm{ArC}) \\
158.4(\mathrm{C}=\mathrm{N}) \\
46.4(\mathrm{CH}) \\
27.8\left(\mathrm{CH}_{2}\right) \\
51.3\left(\mathrm{OCH}_{3}\right)\end{array}$ & $\begin{array}{c}83.0(\mathrm{OC}) \\
77.0(\mathrm{OCH}) \\
22.9\left(\mathrm{CH}_{2}\right) \\
14.8\left(\mathrm{CH}_{3}\right)\end{array}$ & 96.3 \\
\hline 4 & {$\left[\mathrm{Sb}\left(\mathrm{C}_{15} \mathrm{H}_{12} \mathrm{~N}_{2} \mathrm{OX}\right)\left(\mathrm{GO}_{2} \mathrm{PS}_{2}\right)\right] \mathrm{Cl}$} & $\begin{array}{c}144.5-124.9(\mathrm{Ar}-\mathrm{C}) \\
157.9(\mathrm{C}=\mathrm{N}) \\
46.4(\mathrm{CH}) \\
26.6\left(\mathrm{CH}_{2}\right)\end{array}$ & $\begin{array}{c}84.2(\mathrm{OC}) \\
78.4(\mathrm{OCH}) \\
23.0\left(\mathrm{CH}_{2}\right) \\
14.3\left(\mathrm{CH}_{3}\right)\end{array}$ & 93.8 \\
\hline 5 & {$\left[\mathrm{Sb}\left(\mathrm{C}_{15} \mathrm{H}_{12} \mathrm{~N}_{2} \mathrm{OX}\right)_{2}\left(\mathrm{GO}_{2} \mathrm{PS}_{2}\right)\right]$} & $\begin{array}{c}143.9-123.9(\mathrm{Ar}-\mathrm{C}) \\
157.9(\mathrm{C}=\mathrm{N}) \\
46.9(\mathrm{CH}) \\
26.8\left(\mathrm{CH}_{2}\right)\end{array}$ & $\begin{array}{c}85.0(\mathrm{OC}) \\
79.9(\mathrm{OCH}) \\
22.9\left(\mathrm{CH}_{2}\right) \\
14.8\left(\mathrm{CH}_{3}\right)\end{array}$ & 94.5 \\
\hline 6 & {$\left[\mathrm{Sb}\left(\mathrm{C}_{15} \mathrm{H}_{12} \mathrm{~N}_{2} \mathrm{OX}\right)_{2}\left(\mathrm{GO}_{2} \mathrm{PS}_{2}\right)\right]$} & $\begin{array}{c}143.7-123.9(\mathrm{Ar}-\mathrm{C}) \\
158.8(\mathrm{C}=\mathrm{N}) \\
47.0(\mathrm{CH}) \\
27.1\left(\mathrm{CH}_{2}\right) \\
13.8\left(\mathrm{CH}_{3}\right)\end{array}$ & $\begin{array}{c}84.9(\mathrm{OC}) \\
78.3(\mathrm{OCH}) \\
23.0\left(\mathrm{CH}_{2}\right) \\
13.5\left(\mathrm{CH}_{3}\right)\end{array}$ & 99.0 \\
\hline 7 & {$\left[\mathrm{Sb}\left(\mathrm{C}_{15} \mathrm{H}_{12} \mathrm{~N}_{2} \mathrm{OX}\right)_{2}\left(\mathrm{GO}_{2} \mathrm{PS}_{2}\right)\right]$} & $\begin{array}{c}143.5-124.7(\mathrm{Ar}-\mathrm{C}) \\
158.0(\mathrm{C}=\mathrm{N}) \\
47.1(\mathrm{CH}) \\
23.9\left(\mathrm{CH}_{2}\right) \\
51.2\left(\mathrm{OCH}_{3}\right)\end{array}$ & $\begin{array}{c}84.6(\mathrm{OC}) \\
79.9(\mathrm{OCH}) \\
23.1\left(\mathrm{CH}_{2}\right) \\
14.8\left(\mathrm{CH}_{3}\right)\end{array}$ & 95.7 \\
\hline 8 & {$\left[\mathrm{Sb}\left(\mathrm{C}_{15} \mathrm{H}_{12} \mathrm{~N}_{2} \mathrm{OX}\right)_{2}\left(\mathrm{GO}_{2} \mathrm{PS}_{2}\right)\right]$} & $\begin{array}{c}144.5-124.3(\mathrm{Ar}-\mathrm{C}) \\
157.9(\mathrm{C}=\mathrm{N}) \\
47.1(\mathrm{CH}) \\
27.5\left(\mathrm{CH}_{2}\right)\end{array}$ & $\begin{array}{c}85.0(\mathrm{OC}) \\
78.5(\mathrm{OCH}) \\
23.0\left(\mathrm{CH}_{2}\right) \\
13.6\left(\mathrm{CH}_{3}\right)\end{array}$ & 93.0 \\
\hline
\end{tabular}

Notes: $\mathrm{X}=\mathrm{H}$ for $\mathbf{1}$ and $\mathbf{5} ; \mathrm{CH}_{3}$ for 2 and $\mathbf{6} ; \mathrm{OCH}_{3}$ for $\mathbf{3}$ and 7 ; $\mathrm{Cl}$ for $\mathbf{4}$ and $\mathbf{8} ; \mathrm{G}=-{ }^{-}\left(\mathrm{CH}_{3}\right)_{2} \mathrm{CH}_{2} \mathrm{CH}_{(}\left(\mathrm{CH}_{3}\right)$-; $\mathrm{Dtp}=\mathrm{O}, \mathrm{O}$ '-alkylene dithiophosphate

Electronic spectral data for $\left[\mathrm{Sb}\left(\mathrm{C}_{15} \mathrm{H}_{12} \mathrm{~N}_{2} \mathrm{OX}\right)\left(\mathrm{GO}_{2} \mathrm{PS}_{2}\right)\right] \mathrm{Cl}$ and $\left[\mathrm{Sb}\left(\mathrm{C}_{15} \mathrm{H}_{12} \mathrm{~N}_{2} \mathrm{OX}\right)_{2}\left(\mathrm{GO}_{2} \mathrm{PS}_{2}\right)\right]$

\begin{tabular}{|c|c|c|c|}
\hline \multirow{2}{*}{ Comp.no } & \multicolumn{3}{|c|}{ Electronic spectral data, nm } \\
\cline { 2 - 4 } & $\begin{array}{c}\text { I (Pyrazoline) } \\
\left(\pi \rightarrow \pi^{*} \text { and } n \rightarrow \pi^{*}\right)\end{array}$ & $\begin{array}{c}\text { II (Dithiophosphate) } \\
\left(\pi \rightarrow \pi^{*} \text { and } n \rightarrow \pi^{*}\right)\end{array}$ & III Metal $\rightarrow$ ligand \\
\hline 1 & 246 & 289 & $368-350$ \\
\hline 2 & 245 & 289 & $371-349$ \\
\hline 3 & 249 & 299 & $367-349$ \\
\hline 4 & 240 & 278 & $364-350$ \\
\hline 5 & 239 & 288 & $371-345$ \\
\hline 6 & 235 & 286 & $366-347$ \\
\hline 7 & 238 & 298 & $364-349$ \\
\hline 8 & 235 & 284 & $369-349$ \\
\hline
\end{tabular}

Notes: $\mathrm{X}=\mathrm{H}$ for $\mathbf{1}$ and $\mathbf{5} ; \mathrm{CH}_{3}$ for $\mathbf{2}$ and $\mathbf{6} ; \mathrm{OCH}_{3}$ for $\mathbf{3}$ and $7 ; \mathrm{Cl}$ for $\mathbf{4}$ and $\mathbf{8} ; \mathrm{G}=-\mathrm{C}\left(\mathrm{CH}_{3}\right)_{2} \mathrm{CH}_{2} \mathrm{CH}_{(}\left(\mathrm{CH}_{3}\right)-$ 


\section{4. ${ }^{13} \mathrm{C}$ NMR Spectral Studies}

The proton decoupled ${ }^{13} \mathrm{C}$ NMR spectra of $\left[\mathrm{Sb}\left(\mathrm{C}_{15} \mathrm{H}_{12} \mathrm{~N}_{2} \mathrm{OX}\right)\left(\mathrm{GO}_{2} \mathrm{PS}_{2}\right)\right] \mathrm{Cl}$ and $\left[\mathrm{Sb}\left(\mathrm{C}_{15} \mathrm{H}_{12} \mathrm{~N}_{2} \mathrm{OX}\right)_{2}\right.$ $\left.\left(\mathrm{GO}_{2} \mathrm{PS}_{2}\right)\right]$ show the presence of all important signals with reference to $\left[\left(\mathrm{SbC}_{15} \mathrm{H}_{13} \mathrm{~N}_{2} \mathrm{OX}\right)\right] \mathrm{Cl}_{2}$ and $\left[\left(\mathrm{SbC}_{15} \mathrm{H}_{13} \mathrm{~N}_{2} \mathrm{OX}\right)_{2}\right] \mathrm{Cl}$ (Table 4, [16]). The signal observed in the region of 144.6-123.9 ppm as multiplet could be assigned to aromatic carbon [16-21, 27-28]. The signal observed at $\delta=158.9-157.9 \mathrm{ppm}$ due to imino carbon of $\mathrm{C}=\mathrm{N}$ group is shifted to downfield in comparison to the spectra of free pyrazolines (at $\delta=143.5-142.8 \mathrm{ppm}$ ) suggesting the involvement of imino nitrogen in coordination [16-21, 27-28]. ${ }^{13} \mathrm{C}$ NMR spectrum of the compounds shows all important signals with references to O,O'-alkylene dithiophosphate [31].

\section{5. ${ }^{31} \mathrm{P}$ NMR Spectral Studies}

${ }^{31} \mathrm{P}$ NMR chemical shift value showed downfield shifting of about 19-23 ppm in the corresponding dioxaphosphorinane with respect to their parent alkylenedithiophosphoric acids, (77.80-78.58 ppm for dioxaphosphorinane] indicating the bidentate mode of attachment of alkylenedithiophosphate ligand [29-30], (Table 4).

\subsection{Electronic Spectral Studies}

The electronic spectral data for $\left[\mathrm{Sb}\left(\mathrm{C}_{15} \mathrm{H}_{12} \mathrm{~N}_{2} \mathrm{OX}\right)\right.$ $\left.\left(\mathrm{GO}_{2} \mathrm{PS}_{2}\right)\right] \mathrm{Cl}$ and $\left[\mathrm{Sb}\left(\mathrm{C}_{15} \mathrm{H}_{12} \mathrm{~N}_{2} \mathrm{OX}\right)_{2}\left(\mathrm{GO}_{2} \mathrm{PS}_{2}\right)\right]$ complexes are listed in Table 5. In all the antimony complexes, $\pi \rightarrow \pi^{*}$ and $n \rightarrow \pi^{*}$ transitions due to pyrazoline moities exhibit the most intense band in the range of $249-235 \mathrm{~nm}$ [32-34]. The band in the region of 299-278 nm may be attributed to intraligand charge transfer due to dithiophosphate ligand [35]. The third band of comparatively low intensity in the range of $371-345 \mathrm{~nm}$ is attributed to ligand to the metal charge transfer [36].

\subsection{FAB Mass Spectral Studies}

The FAB mass of all the compounds gives a characteristic peak at $\left[\mathrm{M}^{+}\right]$along with other peak showing fragmentation (Scheme 1). The mass spectrum of $\left[\mathrm{Sb}\left(\mathrm{C}_{15} \mathrm{H}_{13} \mathrm{~N}_{2} \mathrm{O}\right)_{2}\left(\mathrm{C}_{6} \mathrm{H}_{12} \mathrm{O}_{2} \mathrm{PS}_{2}\right)\right]$, exhibited the molecular ion peak at $\mathrm{m} / \mathrm{z}=606$ and peaks at $461,368,323,284$ and 189 due to successive removal of $-\mathrm{C}_{9} \mathrm{H}_{9} \mathrm{~N}_{2},-\mathrm{C}_{6} \mathrm{H}_{4} \mathrm{O}$, $-\mathrm{C}_{3} \mathrm{H}_{9},-\mathrm{C}_{3} \mathrm{H}_{3}$ and $-\mathrm{SPO}_{2}$, respectively. The major mass fragment ions are given in Table 6.

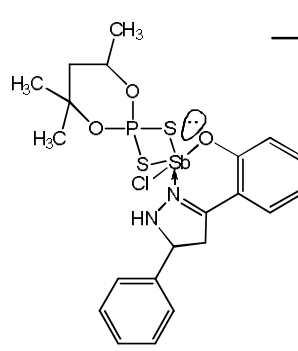

$\mathrm{m} / \mathrm{z}=606$

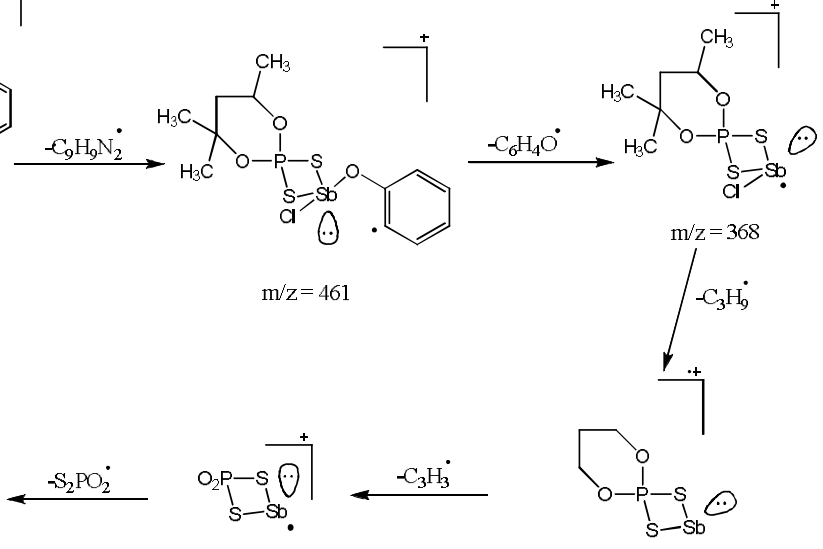

$\mathrm{m} / \mathrm{z}=284$

$\mathrm{m} / \mathrm{z}=323$

Scheme 1. FAB mass fragmentation pattern

of $\left[\mathrm{Sb}\left(\mathrm{C}_{15} \mathrm{H}_{12} \mathrm{~N}_{2} \mathrm{OX}\right)\left(\mathrm{GO}_{2} \mathrm{PS}_{2}\right)\right] \mathrm{Cl} ; \mathrm{G}=-\mathrm{C}\left(\mathrm{CH}_{3}\right)_{2} \mathrm{CH}_{2} \mathrm{CH}\left(\mathrm{CH}_{3}\right)^{-}$

FAB mass spectra of $\left[\mathrm{Sb}\left(\mathrm{C}_{15} \mathrm{H}_{12} \mathrm{~N}_{2} \mathrm{OX}\right)\left(\mathrm{GO}_{2} \mathrm{PS}_{2}\right)\right] \mathrm{Cl}$

\begin{tabular}{|l|c|c|}
\hline \multicolumn{1}{|c|}{ Fragment ion formulae } & \multicolumn{2}{|c|}{$\mathrm{m} / \mathrm{z}$} \\
\hline & $\begin{array}{c}\text { Compound 1, } \mathrm{X}=\mathrm{H} \\
\text { (Relative intensity, \%) }\end{array}$ & $\begin{array}{c}\text { Compound 3, } \mathrm{X}=-\mathrm{OCH}_{3} \\
\text { (Relative intensity, \%) }\end{array}$ \\
\hline$\left|\left(\mathrm{C}_{15} \mathrm{H}_{2} \mathrm{~N}_{2} \mathrm{O} . \mathrm{X}\right) \mathrm{SbCl}_{2}\left(\mathrm{~S}_{2} \mathrm{PO}_{2} \mathrm{C}_{6} \mathrm{H}_{12}\right)\right|^{++}$ & $606(11)$ & $636(12)$ \\
\hline $\left.\mid\left(\mathrm{C}_{6} \mathrm{H}_{5} \mathrm{O}\right) \mathrm{SbCl}_{2} \mathrm{~S}_{2} \mathrm{PO}_{2} \mathrm{C}_{6} \mathrm{H}_{12}\right)\left.\right|^{+}$ & $461(19)$ & $461(22)$ \\
\hline$\left|\mathrm{ClSbS}_{2} \mathrm{PO}_{2} \mathrm{C}_{6} \mathrm{H}_{12}\right|^{+}$ & $368(47)$ & $368(59)$ \\
\hline$\left|\mathrm{SbS}_{2} \mathrm{PO}_{2} \mathrm{C}_{3} \mathrm{H}_{3}\right|^{+}$ & $323(57)$ & $323(59)$ \\
\hline$\left|\mathrm{SbS}_{2} \mathrm{PO}_{2}\right|^{+}$ & $284(100)$ & $284(100)$ \\
\hline$|(\mathrm{SbS})|^{+}$ & $189(52)$ & $189(53)$ \\
\hline
\end{tabular}




\subsection{Antimicrobial Studies}

Comparison of the antimicrobial activity of dichloroantimony(III) pyrazolines, chloroantimony(III) dipyrazolinates, and mixed ligand complexes of antimony(III) with antibiotic terbinafin and kanamycin exhibits the following results (Table 7).

The complexes $\left[\mathrm{Sb}\left(\mathrm{C}_{15} \mathrm{H}_{12} \mathrm{~N}_{2} \mathrm{OX}\right)\left(\mathrm{GO}_{2} \mathrm{PS}_{2}\right)\right] \mathrm{Cl}$ and $\left[\mathrm{Sb}\left(\mathrm{C}_{15} \mathrm{H}_{12} \mathrm{~N}_{2} \mathrm{OX}\right)_{2}\left(\mathrm{GO}_{2} \mathrm{PS}_{2}\right)\right]$ exhibit greater antibacterial effect towards Bacillus subtilis, Pseudomonas sp., S. aureus,
K. pneumoniae, Vibrio sp., and E. coli compared to dichloroantimony(III) pyrazolinates and chloroantimony(III) dipyrazolinates and kanamycin (Fig. 1). But their antifungal effect towards Aspergillus flavus and Penicillium chrysogenum was less compared to chloroantimony(III) dipyrazolinates and terbinafin (Fig. 2). The mixed ligand complexes of antimony(III) also show significant antiviral activity with inhibition of about $34.30 \%$ (Table 8 ).

Antimicrobial activity of the dichloroantimony(III) pyrazolinate, chloroantimony(III) dipyrazolinate, $\left[\mathrm{Sb}\left(\mathrm{C}_{15} \mathrm{H}_{12} \mathrm{~N}_{2} \mathrm{OX}\right)\left(\mathrm{GO}_{2} \mathrm{PS}_{2}\right)\right] \mathrm{Cl}$ and $\left[\mathrm{Sb}\left(\mathrm{C}_{15} \mathrm{H}_{12} \mathrm{~N}_{2} \mathrm{OX}\right)_{2}\left(\mathrm{GO}_{2} \mathrm{PS}_{2}\right)\right]$

\begin{tabular}{|c|c|c|c|c|c|c|c|c|}
\hline \multirow{2}{*}{ Number } & \multicolumn{3}{|c|}{ Fungi } & \multicolumn{2}{c|}{ Gram (+ve) bacteria } & \multicolumn{5}{c|}{ Gram (-ve) bacteria } \\
\cline { 2 - 10 } & A. flavus & P. chrysogenum & S. aureus & B.subtilis & K. pneumoniae & Vibrio spp. & E. coli & P. aeruginosa \\
\hline 1 & ++++ & +++ & +++ & +++ & +++ & +++ & ++ & ++++ \\
\hline 2 & ++ & +++ & +++ & ++ & ++ & ++ & + & ++ \\
\hline 3 & +++ & ++ & +++ & +++ & +++ & +++ & ++ & ++ \\
\hline 4 & ++ & ++ & +++ & ++ & +++ & ++ & + & +++ \\
\hline 5 & ++ & +++ & +++ & +++ & +++ & +++ & ++ & +++ \\
\hline
\end{tabular}

Notes: Inhibition values beyond control are: $+6-10 \mathrm{~mm},++11-15 \mathrm{~mm},+++16-20 \mathrm{~mm},++++21-25 \mathrm{~mm}$ (the values are including disc diameter).

The standards are in the form of sterile Whatmann's filter paper disc, each disc containing $30 \mu \mathrm{g}$ of the drug.

1 - Terbinafin (antifungal agent) and kanamycin (antibacterial agent); $2^{-}$dichloroantimny (III) [3(2'-hydroxyphenyl)-5phenyl pyrazolinate]; 3 - chloroantimny(III) di[3(2'-hydroxyphenyl)-5-phenyl pyrazolinate]; 4 - comp. no. 1 and 5 - comp. no. 5 from Table 1.

Table 8

Antiviral activity of $\left[\mathrm{Sb}\left(\mathrm{C}_{15} \mathrm{H}_{12} \mathrm{~N}_{2} \mathrm{OX}\right)\left(\mathrm{GO}_{2} \mathrm{PS}_{2}\right)\right] \mathrm{Cl}$ and $\left[\mathrm{Sb}\left(\mathrm{C}_{15} \mathrm{H}_{12} \mathrm{~N}_{2} \mathrm{OX}\right)_{2}\left(\mathrm{GO}_{2} \mathrm{PS}_{2}\right)\right]$

\begin{tabular}{|c|c|c|}
\hline Comp.no & Compound & Inhibition, \% \\
\hline 1 & {$\left[\mathrm{Sb}\left(\mathrm{C}_{15} \mathrm{H}_{13} \mathrm{~N}_{2} \mathrm{O}\right)\left(\mathrm{GO}_{2} \mathrm{PS}_{2}\right)\right] \mathrm{Cl}$} & 26.12 \\
\hline 3 & {$\left[\mathrm{Sb}\left(\mathrm{C}_{15} \mathrm{H}_{12} \mathrm{~N}_{2} \mathrm{OOCH}_{3}\right)\left(\mathrm{GO}_{2} \mathrm{PS}_{2}\right)\right] \mathrm{Cl}$} & 43.56 \\
\hline 5 & {$\left[\mathrm{Sb}\left(\mathrm{C}_{15} \mathrm{H}_{12} \mathrm{~N}_{2} \mathrm{OCl}\right)\left(\mathrm{GO}_{2} \mathrm{PS}_{2}\right)\right]$} & 46.32 \\
\hline 7 & {$\left[\mathrm{Sb}\left(\mathrm{C}_{15} \mathrm{H}_{13} \mathrm{~N}_{2} \mathrm{O}\right)_{2}\left(\mathrm{GO}_{2} \mathrm{PS}_{2}\right)\right]$} & 34.09 \\
\hline 8 & {$\left[\mathrm{Sb}\left(\mathrm{C}_{15} \mathrm{H}_{12} \mathrm{~N}_{2} \mathrm{OOCH}_{3}\right)\left(\mathrm{GO}_{2} \mathrm{PS}_{2}\right)\right]$} & 26.45 \\
\hline
\end{tabular}

Notes: $\mathrm{G}=-\mathrm{C}\left(\mathrm{CH}_{3}\right)_{2} \mathrm{CH}_{2} \mathrm{CH}\left(\mathrm{CH}_{3}\right)$. Inhibition was calculated according to the formula (1)

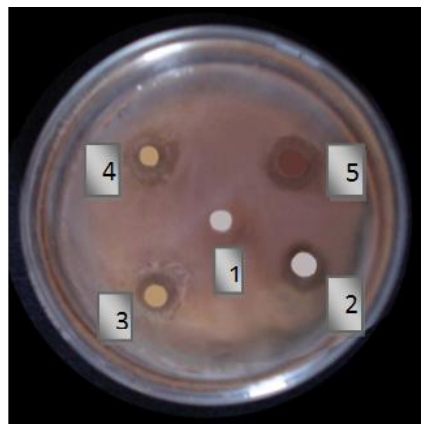

Fig. 1. Antibacterial activity against Bacillus subtilis: DMSO (1); kanamycin (2); dichloroantimony(III) pyrazolines (3); chloroantimony(III) dipyrazolinates (4) and $\left[\mathrm{Sb}\left(\mathrm{C}_{15} \mathrm{H}_{12} \mathrm{~N}_{2} \mathrm{OCl}\right)_{2}\left(\mathrm{C}_{6} \mathrm{H}_{12} \mathrm{O}_{2} \mathrm{PS}_{2}\right)\right](5)$

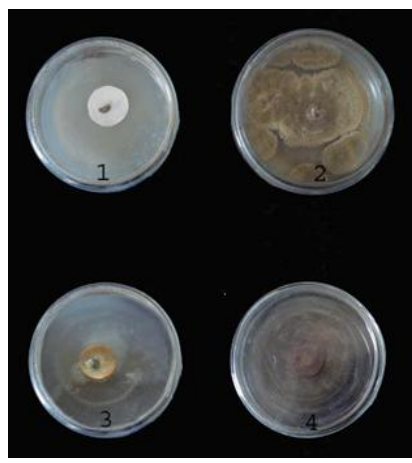

Fig. 2. Antifungal activity against Aspergillus flavus: terbinafin (1); DMSO (2); chloroantimony(III) dipyrazolinates (3) and $\left[\mathrm{Sb}\left(\mathrm{C}_{15} \mathrm{H}_{13} \mathrm{~N}_{2} \mathrm{O}\right)_{2}\left(\mathrm{C}_{6} \mathrm{H}_{12} \mathrm{O}_{2} \mathrm{PS}_{2}\right)\right]$ (4) 


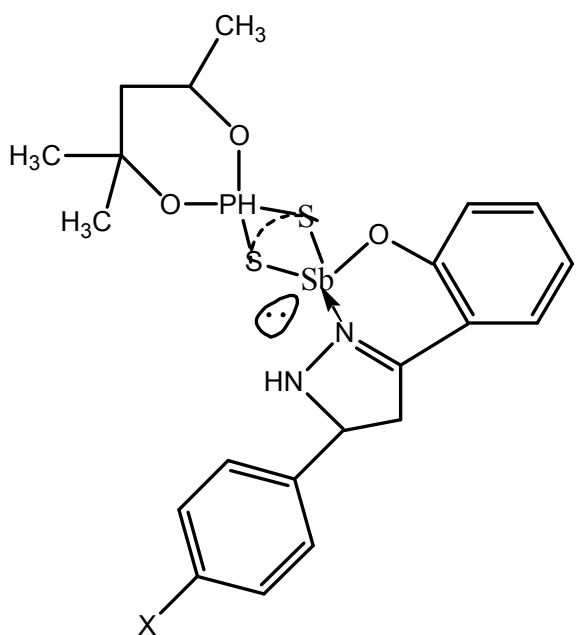

Fig. 3. Proposed structure for $\left[\mathrm{Sb}\left(\mathrm{C}_{15} \mathrm{H}_{12} \mathrm{~N}_{2} \mathrm{OX}\right)\left(\mathrm{C}_{6} \mathrm{H}_{12} \mathrm{O}_{2} \mathrm{PS}_{2}\right)\right] \mathrm{Cl}$, where $\mathrm{X}=-\mathrm{H},-\mathrm{CH}_{3},-\mathrm{OCH}_{3}$ and $\mathrm{Cl}$

So, the geometry for compounds no.1-4 shows a trigonal bipyramidal geometry with coordination number five and compound number 5-8 would be distorted pentagonal bipyramidal geometry with coordination number six (Figs 3-4). Besides this, the synthesized compounds are biologically active.

\section{Conclusions}

It can be concluded that complexation of substituted antimony(III) moiety with biologically active pyrazoline ligand results in increased activity of these complexes. It appears that when chlorine in chloroantimony(III) dipyrazolinates is replaced by O,O'alkylene dithiophosphates moiety, there is a significant change in antimicrobial activity of these complexes. This concludes that antimicrobial activity of these complexes arises from pyrazoline moiety and antimicrobial activity increases when chlorine atom is replaced by the $\mathrm{O}, \mathrm{O}^{\prime}-$ alkylenedithiophosphate moiety.

\section{References}

[1] Garji S., Jain V.: Coord. Chem. Rev., 2003, 236, 35.

https://doi.org/10.1016/S0010-8545(02)00159-5

[2] Lee M., Gilbert H.: Infect. Med., 1999, 16, 37.

[3] Yu L., Ma Y-Q., Liu R-C. et al.: Polyhedron, 2004, 23, 823.

https://doi.org/10.1016/j.poly.2003.12.002

[4] Chauhan H.: Coord. Chem. Rev., 1998, 173, 1.

https://doi.org/10.1016/S0010-8545(97)00071-4

[5] Silvestru C., Socacia C., Bara A., Haiduc I.: J. Anticancer Res., 1990, 10, 803.

[6] Jung J., Watkins E., Avery M.: Hetrocycles, 2005, 65, 77. https://doi.org/10.3987/COM-04-10216

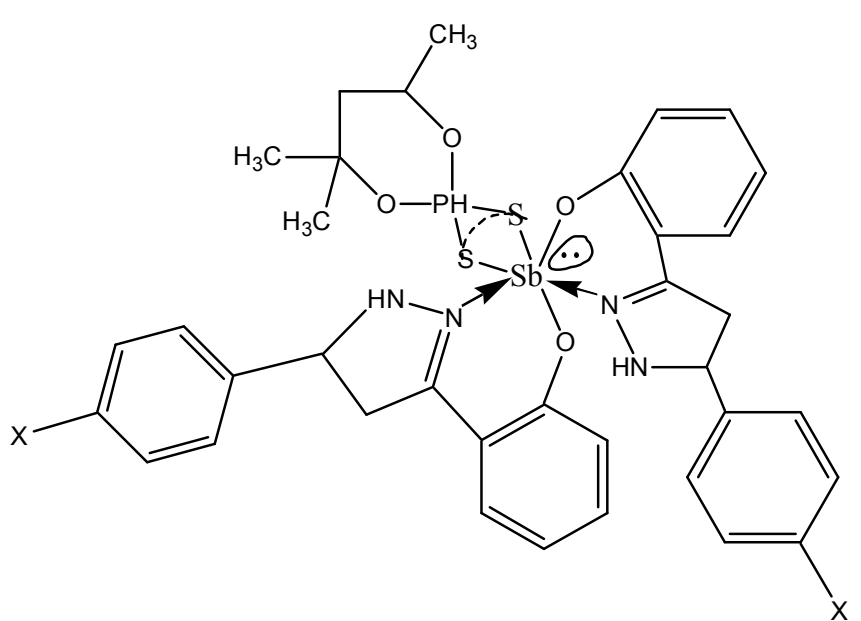

Fig. 4. Proposed structure for $\left[\mathrm{Sb}\left(\mathrm{C}_{15} \mathrm{H}_{12} \mathrm{~N}_{2} \mathrm{OX}\right)_{2}\left(\mathrm{C}_{6} \mathrm{H}_{12} \mathrm{O}_{2} \mathrm{PS}_{2}\right)\right]$, where $\mathrm{X}=-\mathrm{H},-\mathrm{CH}_{3},-\mathrm{OCH}_{3}$ and $\mathrm{Cl}$

[7] Hamman A., Fahmy A., Amr A., Mohamad A.: Indian J. Chem., 2003, 42B, 1985.

[8] Braenden O., Reddy N., Habach B.: Bull. World Health Org., 1955, 13, 935.

[9] Soloman W., Ravi J., Annadwai K.: Indian Drugs, 1999, 36, 466.

[10] Bansal E., Srivastava V., Kumar A.: Eur. J. Med. Chem., 2001, 36, 81. https://doi.org/10.1016/S0223-5234(00)01179-X

[11] Malhotra V., Pathak S., Nath R. et al.: Indian J. Chem., 2002, 41B, 1310.

[12] Palasha E., Aytemir M., Uzbay I., Erol D.: Eur. J. Med. Chem., 2001, 36, 539. https://doi.org/10.1016/S0223-5234(01)01243-0

[13] Mastin R.: Chem. Abstr., 1983, 43, 11782.

[14] Shah J., Shah N.: Indian J. Chem., 1982, 21 A, 312.

[15] Shah J., Shah N.: J. Inorg. Nucl. Chem., 1981, 43, 1593. https://doi.org/10.1016/0022-1902(81)80342-9

[16] Tripathi U., Ahmad M., Solanki J., Bhardwaj A.: J. Coord. Chem., 2009, 62, 636. https://doi.org/10.1080/00958970802244976 [17] Tripathi U., Solanki J., Bhardwaj A., Thapak T.: J. Coord. Chem., 2008, 61, 4025.

https://doi.org/10.1080/00958970802199964

[18] Tripathi U., Ahmad M., Solanki J. et al.: Turkis J. Chem., 2009, 33, 257.

[19] Tripathi U., Venubabu G., Ahmad M. et al.: J. Appl.

Organomet. Chem., 2006, 20, 669. https://doi.org/10.1002/aoc.1074

[20] Tripathi U., Ahmad M., Venubabu G., Ramakrishna P.: J.

Coord. Chem., 2007, 60, 1777.

https://doi.org/10.1080/00958970601183391

[21] Tripathi U., Ahmad M., Venubabu G., Ramakrishna P.: J. Coord. Chem., 2007, 60, 1709.

https://doi.org/10.1080/00958970601110865

[22] Tripathi U., Ahmad M.: Main Group Met. Chem., 2004, 27, 21. https://doi.org/10.1515/MGMC.2004.27.1.21

[23] Ratnani R., Srivastava G., Mehrotra R.: Inorg. Chem. Acta, 1989, 161, 253. https://doi.org/10.1016/S0020-1693(00)83101-1 [24] Vogel A.: A Text Book of Quantitative Inorganic Analysis. ELBS and Longman Group Ltd., London 1985.

[25] Hasan M., Das R., Khan A. et al.: Adv. Biolog. Res., 2009, 3, 56. 
[26] Mishra A., Rao G.: Phytophylactica, 1988, 20, 162.

[27] Tripathi U., Siddiqui A., Ahmad M., Singh K.: J. Coord. Chem., 2010, 63, 894. https://doi.org/10.1080/00958971003645920 [28] Tripathi U., Siddiqui A., Ahmad M. et al.: Main Group Met. Chem., 2010, 33, 25. https://doi.org/10.1515/MGMC.2010.33.12.25

[29] Tripathi U., Sharma D., Jain N., Soni M.: Phosphorus Sulphur, 2007, 182, 133. https://doi.org/10.1080/10426500601091063

[30] Tripathi U., Ahmad M., Mirza R., Siddiqui A.: Phosphorus Sulphur, 2007, 182, 1. https://doi.org/10.1080/10426500701313961 [31] Chauhan H., Singh U.: Appl. Organomet. Chem., 2007, 21, 880. https://doi.org/10.1002/aoc. 1290

[32] Tripathi U., Sharma K., Chaturvedi A., Sharma T.: Polish J. Chem., 2003, 77, 109.

[33] Shaha N., Sau D.: Transit. Metal Chem., 2005, 30, 532. https://doi.org/10.1007/s11243-005-1029-y

[34] Tripathi U., Siddiqui A., Ahmad M., Singh K.: J. Coord. Chem., 2010, 63, 894. https://doi.org/10.1080/00958971003645920

[35] Chauhan H., Singh U.: Appl. Organomet. Chem., 2007, 21, 880. https://doi.org/10.1002/aoc.1290

[36] Kheiri F., Tsipis C. et al.: Can. J. Chem., 1979, 57, 767. https://doi.org/10.1139/v79-125

\section{ФІЗИКО-ХІМІЧНА ХАРАКТЕРИСТИКА БІОАКТИВНИХ ЛІГАНДНИХ КОМПЛЕКСІВ СУРМИ 3 3,5-ДІАРИЛЗАМІЩЕНИМИ ПІРАЗОЛІНАТАМИ І О, О'-АЛКІЛЕН ДІТІОФОСФАТАМИ}

Анотація. Синтезовані комплекси сурми 3(2'-гідроксифеніл)-5-(4'-заміщений феніл)піразолінат з О,O'-алкілен дитіофосфатом типу $\left[\mathrm{Sb} \quad\left(\mathrm{C}_{15} \mathrm{H}_{12} \mathrm{~N}_{2} \mathrm{OX}\right)\left(\mathrm{GO}_{2} \mathrm{PS}_{2}\right)\right] \mathrm{Cl} \quad \mathrm{ma}$ $\left[\mathrm{Sb}\left(\mathrm{C}_{15} \mathrm{H}_{12} \mathrm{~N}_{2} \mathrm{OX}\right) 2\left(\mathrm{GO}_{2} \mathrm{PS}_{2}\right)\right]$ (де $\mathrm{GO}_{2} \mathrm{PS}_{2}$ - депротонований O,O'алкілен дитіофосфат; $\mathrm{C}_{15} \mathrm{H}_{12} \mathrm{~N}_{2} \mathrm{OX}$ - депротонований 3(2'гідроксифеніл)-5-(4'-замімений феніл)піразолінат; $\mathrm{X}=-\mathrm{H},-\mathrm{CH}_{3}$, $\left.-\mathrm{OCH}_{3} \mathrm{ma}-\mathrm{Cl} ; \mathrm{G}=-\mathrm{C}\left(\mathrm{CH}_{3}\right)_{2} \mathrm{CH}_{2} \mathrm{CH}(\mathrm{CH} 3)-\right)$. Проведені дослідження синтезованих сполук за допомогою елементного аналізу (C, $\mathrm{H}, \mathrm{N}, \mathrm{Cl}$ i Sb), бомбардування швидкими атомами, електронних спектральних досліджень, ІЧ-спектроскопії, багатоядерного ЯМР $\left({ }^{1} \mathrm{H},{ }^{13} \mathrm{C}\right.$ та $\left.{ }^{31} \mathrm{P}\right)$. На основі одержсаних даних розглянуто координацію дитіофосфату та піразолінатів, а також структуру сполук. За результатали тестів іп vitro встановлено, щчо синтезовані комплекси мають непогану антибактеріальну та протигрибкову активність. Результати досліджень деяких зразків на активність проти папайського рингпот-вірусу, показали значну антивірусну активність з інгібуванням приблизно $34,30 \%$.

Ключові слова: антибактеріальна активність, антивірусна активність, сурма(III), піразолінати, дитіофосфати. 